\title{
Contrasting contrastive demonstratives in Tiriyó and Lavukaleve
}

\author{
SÉRGIO MEIRA AND ANGELA TERRILL
}

\section{Abstract}

This article explores the contrastive function of demonstratives in two languages, Tiriyó (Cariban, northern Brazil) and Lavukaleve (Papuan isolate, Solomon Islands). The contrastive function has to a large extent been neglected in the theoretical literature on demonstrative functions, although preliminary investigations suggest that there are significant differences in demonstrative use in contrastive versus noncontrastive contexts. Tiriyo and Lavukaleve have what seem at first glance to be rather similar three-term demonstrative systems for exophoric deixis, with a proximal term, a distal term, and a middle term. However, under contrastive usage, significant differences between the two systems become apparent. In presenting an analysis of the contrastive use of demonstratives in these two languages, this article aims to show that the contrastive function is an important parameter of variation in demonstrative systems.

\section{Introduction ${ }^{1}$}

The exophoric use of demonstratives (i.e. external reference to real objects in space), though often described as the "main" or "basic" meaning of demonstrative terms, has actually had very few empirical studies in specific languages. Descriptions usually employ labels derived from the situation in better known European languages ("proximal," "medial," "distal"), based on a few instances observed in situ. ${ }^{2}$ Ongoing research at the Max Planck Institute for Psycholinguistics in Nijmegen suggests that such descriptions are often oversimplifications: these labels often describe systems which are markedly different in actual use. For instance, English and Russian belong to the set of languages with two demonstrative terms, usually labeled "proximal" (English this, Russian ètot) and "distal" (English that, Russian tot); however, it is often not the case that 
terms with the same label are translation equivalents. English that can be used in contrastive contexts when talking about one's own body (e.g. This finger doesn't hurt, but that finger does, with the speaker presenting two of his/her fingers in succession); in Russian, tot would be impossible. (See Dunn and Meira [in prep.] for further details.)

The Russian-English example above suggests that a further distinction between contrastive and noncontrastive exophoric use can profitably be introduced in the study of exophoric uses of demonstratives (see Wilkins 1999). "Contrastive use" labels situations in which demonstratives are employed to contrast more than one possible referent (e.g. I wanted that book, not this book), whereas "noncontrastive" situations are those in which no such contrast between possible referents is envisaged (e.g. What is that thing on the table?). Note that the contrastive and noncontrastive uses of the same demonstratives may differ: the use of English that to refer to a part of the speaker's body is possible in contrastive situations (such as the example given in the preceding paragraph), but apparently not otherwise.

Prior to Wilkins (1999), the literature on demonstratives does not seem to make many mentions of contrastive uses as significantly different from noncontrastive uses. The most significant seems to be Fillmore (1982: 54), who discussed "serial order" (illustrated by the English sentence Do you want this one or that one?) as one of the uses of demonstrative categories. Fillmore mentions that languages can differ in their uses of demonstratives, which he illustrated for "serial order" with the Bakwiri distal, which, unlike its English counterpart, is very often used for the second of two objects (= 'the other'). However, Fillmore apparently considered this an ad hoc, less important feature: the Bakwiri term is defined as basically distal, with the contrastive use as a peripheral "usage note" (Fillmore 1982: 57).

Typological studies have accordingly paid little or no attention to contrastive contexts. Anderson and Keenan (1985) do not discuss them in general, although they do mention the contrastive function of some demonstratives. ${ }^{3}$ Himmelmann (1996) and Diessel (1999) do not mention the contrastive use of demonstratives as possibly independent from noncontrastive uses. Similarly, Dixon (2003: 80-82) collapses both uses in his "deictic function." Contrastive usage is also not treated per se in the semantic and pragmatic literature on deixis (e.g. Lyons 1977; Levinson 1983; Marmaridou 2000); rather, cases with several potential referents are treated as simple extensions of cases with one potential referent (with the "distance" feature being deployed to distinguish the desired referent).

This study is a first attempt at examining contrastive demonstrative usage in its own terms. Although contrastive usage is not strictly limited to 
exophoric contexts (it occurs in endophoric, i.e., text-internal contexts in at least certain languages), its most frequent and possibly prototypical form appears to be exophoric. For this reason, we have chosen to concentrate on the exophoric contrastive use of demonstratives in two languages in detail: Tiriyó (a Cariban language spoken in northern Brazil) and Lavukaleve (a Papuan isolate of the Solomon Islands). The extension of this study to endophoric contexts is left for future research. This study emerged from a larger survey (carried out by members of the Language and Cognition Group of the Max Planck Institute for Psycholinguistics). Tiriyó and Lavukaleve make a particularly interesting comparison because they have at first sight very similar exophoric demonstrative systems: both have three demonstrative terms used for exophoric reference, including what could be roughly described as proximal, middle, and distal terms. In both cases, the terms are not sensitive to the position of the addressee. ${ }^{4}$ While the proximal and distal terms are roughly equivalent in the two languages, both speaker-anchored and referring to comparable domains, the "middle" terms are actually not identical, although very similar. In neither language is the middle term a medial, referring to a distance somewhere in between the proximal and distal terms. Rather, in both languages, the middle term (called "unmarked distal" in Tiriyó and "neutral" in Lavukaleve $)^{5}$ is used if neither the proximal nor distal terms apply. But the meanings of the middle terms differ, as the different descriptive labels suggest.

In Tiriyó, the middle term in noncontrastive exophoric usage refers to distal referents, but it does not have a range of reference unique to itself, to which the proximal or distal terms cannot also apply. It is semantically less marked than the other terms, but still has distance-related meanings, in that it is best applied to scenes with a distal referent, but less marked than the true distal term (Meira forthcoming).

In Lavukaleve, by contrast, the middle term is distance-neutral; its meaning does not include distance specifications. It gains pragmatic meaning only from its opposition to the proximal (close to speaker) and distal (far from speaker) terms; when it is used, the inference is that the referent is neither saliently close to nor saliently far from the speaker (Terrill 2003, forthcoming).

Under contrastive usage, the difference between the two middle terms becomes very visible: while the Tiriyó middle term actually does occur in contrastive contexts, the Lavukaleve middle term does not. The comparison between the two systems sketched here is then an example of how systems that at first sight look very similar may in fact present considerable differences at a deeper level. 
We will first outline the research methodology before examining each language in turn. In our final discussion we compare the two systems.

\section{Methodology}

Data was collected by means of an elicitation task, conducted in situ in Brazil by Meira for Tiriyó, and in the Solomon Islands by Terrill for Lavukaleve.

The procedure which was used to collect the data for the comparison of Tiriyó and Lavukaleve was David Wilkins' "contrastive demonstrative elicitation task" (described in detail in Wilkins 1999). The basic idea is similar to that of a memory game. On a notepad or a piece of white cardboard, the researcher (sitting beside the speaker) places small square pieces of paper (e.g. post-it notes). Each piece has a drawing - a circle, a square, a star, etc., or any combination of culturally adequate items which the speaker is allowed to see. Afterwards, the researcher places the post-it notes face down on the board on the sagittal axis in front of the speaker (i.e. so that the pieces of paper are at obviously different distances from the speaker). The speaker is then asked which post-it note hides which drawing (with questions of the form: Now, which one is the little star? And which one is the little circle?, etc.). This can be repeated several times, with different placements for the post-it notes over the notepad. The post-it notes can be kept equidistant from each other, or can be clustered (e.g. two of them closer to each other, the third one farther away). Variations of the task involve just two post-it notes, then three post-it notes at equal distances, then at varying distances, four post-it notes, and so on. The answers of the speaker must be recorded, so that patterns in the answers can be studied (including, for instance, the preferred order of mention - is it more natural to mention the closest object first? - the co-occurrence of pointing and/or gesture, etc.). Since this is an elicitation task, the researcher can also ask further questions of the speaker (e.g. Could you have used this term instead of that when referring to this object? Could you have referred to this one first with this term, and then to that one with this other term? Would you say the same if you could not touch or point at the objects? etc.).

\section{Tiriyó}

The Tiriyó demonstratives can be seen as part of a larger system of third person pronouns, a form class which includes also endophoric (in this case, anaphoric) elements (cf. Table 1 below, in which a first analysis of 
Table 1. Tiriyó third person pronouns (after Meira forthcoming) ${ }^{7}$

\begin{tabular}{|c|c|c|c|c|}
\hline & \multicolumn{2}{|c|}{ Inanimate } & \multicolumn{2}{|c|}{ Animate } \\
\hline & Non-collective & Collective & Non-collective & Collective \\
\hline Anaphoric & irë & irëto(mo) & nërë & namo \\
\hline \multicolumn{5}{|l|}{ Demonstrative } \\
\hline \multicolumn{5}{|l|}{ Accessible } \\
\hline Proximal & se(ni) & $\operatorname{sento}(m o)$ & mëe & mëesa (mo) \\
\hline & serë & serëto $(m o)$ & & \\
\hline Distal unmarked & mere & mërëto (mo) & mёёrё & mёёја (mo) \\
\hline Distal marked & ooni & oonito (mo) & ohkï & ohkïja (mo) \\
\hline Inaccessible & $m \ddot{e}(n \ddot{\imath})$ & mënto(mo) & $m \ddot{k} \ddot{\imath}$ & mëkïja(mo) \\
\hline
\end{tabular}

the system is sketched). The same forms can be used independently ('that is good') or as modifiers ('that book is good'), as can be seen in (1)-(2). ${ }^{6}$ There is also no independent set of demonstrative adverbs ('here', 'there') corresponding to the pronouns; rather, a demonstrative pronoun with a locative postposition is used ('there' = 'at that (one)'; cf. [3]).

(1) ё-mёmparë mërë?

2-belonging DEM.MD.INAN ${ }^{8}$

'Is that yours?' (referent at approximately $10 \mathrm{~m}$ from both speaker and hearer)

(2) kura-no serë(,) tëpu

pretty-NZR DEM.PX.INAN stone

'This stone is pretty.' (referent in the speaker's hands)

(3) ooni po nai(,) ji-pata

DEM.DS.INAN LOC 3.COP 1-place

'My place (village) is there.' (pointing at an inaccessible place, far away).

(4) atï mën?

Wh.INAN DEM.INACC

'What is that?' (referring to a far-away diesel motor; its noise was clearly audible)

(5) irë wï-ka!

DEM.ANAPH.INAN 1-Say:PST

'That's what I said!' (= 'yes, what you said is what I think'; the speaker is referring to what his interlocutor had just said)

As can be seen in Table 1, the Tiriyó demonstrative system is sensitive to animacy and number. The animacy category is semantically quite transparent: animate forms are used for persons and animals, including insects, 
and inanimate forms are used for everything else (including trees, plants, and moving objects like planes or cars; the examples above are all inanimate forms). ${ }^{9}$ The number category is traditionally analyzed as opposing "less than all" (non-collective) to "all" (collective) rather than "one" (singular) to "more than one" (plural). This seems to be by and large true for Tiriyó, though some inconsistencies are attested and suggest that more research on the semantics of number is needed.

The focus of this article is on the distance-related forms in Table 1, thus excluding the anaphoric and the inaccessible forms. This leaves three terms, which are labeled proximal, distal unmarked (the so-called "middle" term in this article), and distal marked in Table 1. Here, the contrastive uses of these terms, as reflected in the results of the contrastive demonstrative task, will be brought into the picture. ${ }^{10}$

\subsection{Results of the contrastive demonstrative task}

The contrastive task was carried out with five male speakers in five independent sessions. Three of the sessions were videotaped; two of them were simply transcribed on a field notebook. In each session, the speakers first went through the two-referent (pieces of paper) subtask, and then through the three-referent subtask. The speakers had their own spontaneous reactions, often more than once. Every spontaneous usage of a demonstrative term in the task was recorded as such. Afterwards, speakers were also asked if certain combinations would be acceptable (Can I also say mërë first and then serë?); these answers were noted down as nonspontaneous reactions. The occurrence of pointing and/or touching was also recorded, as well as the order in which the objects were referred to. A transcription of a full session appears in the Appendix.

The results of the task are displayed in Tables $2-5$ below. The first column contains a drawing which represents the speaker and the referents in order of distance (the referent in the first row is the most distant one, the one in the second row the second most distant one, and so on). The

Table 2. Two referents displayed on the sagittal axis in front of the speaker, with speaker either touching or closely pointing

\begin{tabular}{|c|c|c|c|c|}
\hline Good & & & & $\mathrm{Bad}$ \\
\hline se(nï) (РX) & serë (PX) & serë (PX) & se(nï) (Рx) & anything else \\
\hline serë (PX) & se(nï) (Рx) & serë (PX) & se(nï) (Рx) & \\
\hline$(4: 2)$ & $(4: 2)$ & $(3: 2)$ & $(3: 2)$ & $(2: 2)$ \\
\hline
\end{tabular}


Table 3. Two referents displayed on the sagittal axis in front of the speaker, with speaker not touching the referents and pointing only from a distance

\begin{tabular}{|c|c|c|c|c|c|c|}
\hline Good & & & & & & $\mathrm{Bad}$ \\
\hline mërë (MD) & mërë (MD) & ooni (DT) & ooni (DT) & ooni (DT) & mërë (MD) & anything \\
\hline serë (PX) & se(nï) (Рx) & se(nï) (Рх) & mërë (MD) & serë (PX) & mërë (MD) & ooni (DT) \\
\hline$(5: 3)$ & $(4: 2)$ & $(4: 3)$ & $(4: 3)$ & $(3: 2)$ & $(1: 1)$ & $(2: 2)$ \\
\hline
\end{tabular}

Table 4. Three referents displayed on the sagittal axis in front of the speaker, with speaker either touching or closely pointing

\begin{tabular}{|c|c|}
\hline Good & $\mathrm{Bad}$ \\
\hline se(nï) / serë ( $\mathrm{PX})$ & \\
\hline se(nï) / serë ( $\mathrm{PX})$ & anything else \\
\hline se(nï) / serë (PX) & \\
\hline$(3: 3)$ & $(1: 1)$ \\
\hline
\end{tabular}

Table 5. Three referents displayed on the sagittal axis in front of the speaker, with speaker not touching the referents and pointing only from a distance

\begin{tabular}{|c|c|c|c|c|c|c|}
\hline Good & & & & & & $\mathrm{Bad}$ \\
\hline ooni (DT) & mërë (MD) & ooni (DT) & ooni (DT) & ooni (DT) & mërë (MD) & \\
\hline mërë (MD) & $\begin{array}{l}\text { se(nï) / } \\
\text { serë (PX) }\end{array}$ & ooni (DT) & se(nï) (Px) & ooni (DT) & mërë (MD) & $\begin{array}{l}\text { anything } \\
\text { else }\end{array}$ \\
\hline 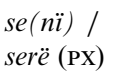 & $\begin{array}{l}\text { se(nï) / } \\
\text { serë (Px) }\end{array}$ & $\begin{array}{l}\text { se(nï) / } \\
\text { serë (Px) }\end{array}$ & serë (PX) & mërë (MD) & serë (MD) & \\
\hline$(6: 4)$ & $(4: 3)$ & $(2: 1)$ & $(1: 1)$ & $(1: 1)$ & $(1: 1)$ & $(1: 1)$ \\
\hline
\end{tabular}

demonstratives that occurred are then shown in the following columns, roughly in order of adequacy. At the bottom of each column, the corresponding number of answers and speakers who produced the answers is given in parentheses. Thus, in the first column of Table 3, the numbers (5:3) indicate that there were five positive answers for this particular configuration (serë for the closer referent and mërë for the farther referent) from three different speakers (i.e. two speakers reacted more than once). 


\subsection{Discussion of results}

Based on the results of the contrastive task, the following observations can be made:

(a) All three spatial terms can be used for contrast. None of the terms which occurred in noncontrastive exophoric contexts (serë/se(nï), mërë, ooni) failed to be used also in this contrastive elicitation context.

(b) The distinction between the two proximals serë and se(nï) does not seem to depend on distance. With two referents, as one can see in Tables 2 and 3, serë and se (nï) occur in the same cases, with quite similar frequencies. In Tables 4 and 5, the occurrences of $s e(n \ddot{i})$ and serë were no longer kept distinct.

(c) Close pointing and/or touching affect demonstrative choice. As might be expected, closely pointing to the referent or touching it favor the choice of proximal terms. Whenever one of the referents was touched by the speaker, only the proximals serë and se(nï) were used, and any attempts at using other terms were promptly refused.

(d) The order of mention or pointing did not matter. If there was no touching or close pointing, the order in which referents were mentioned did not affect the choice made. Thus, the farthest referent was always referred to with a "more distal" term (ooni or mërë), while the closest referents always elicited a "more proximal" term (serë/se(nï) or mërë), regardless of whether it was the first to be mentioned or not.

(e) With two referents, all spatially logical combinations occurred: proximal-medial (sërë/se(nï)-mërë), proximal-distal (serë/se(nï)ooni), and medial-distal (mërë-ooni). Actual distance influences the choices: with two referents, for instance, the medial-distal option (mërë-ooni) was always a result of a "distancing" technique (either moving both referents farther away from the speaker and asking again, or, in one case, explicitly asking the speaker not to point with his fingers, which caused the speaker to cross his arms and elicited gaze- and lip-pointing). With three referents, cases of ooni-mërë-mërë (distal-medial-medial) and mërë-mërë-serë (medial-medial-proximal) were also obtained by moving the referents farther away from the speaker. The cases of ooni-ooni-serë / se(nï) (distal-distal-proximal) were likewise obtained by moving the first two referents farther away from the speaker while keeping the first referent at its original distance. However, the case 
of ooni-se(nï)-serë (distal-proximal-proximal) and the four cases of mërë-se(nï)/serë-se(nï)/serë (medial-proximal-proximal) occurred spontaneously with the referents at the same distance which elicited the ooni-mërë-se(nï)/serë (distal-medial-proximal) choices.

\subsection{Conclusions}

Speakers use Tiriyó demonstratives contrastively to indicate different areas in table-top space. As far as could be ascertained, the distancerelated terms do indeed refer to table-top areas located at increasing distances from the speaker, with "proximal" referring to those areas closest to the speaker, "distal marked" referring to those areas furthest from the speaker, and "distal unmarked" referring to an intermediate region between these two (although speakers can disagree, or even change their minds, as to the limits of those zones). The difference between the two proximal terms, serë and se(ni)), is apparently not based on distance, since, as far as could be ascertained, they occurred interchangeably in the same contexts. ${ }^{11}$ Close point and/or touching had the effect of destroying the "zoning": referents closely pointed at or touched, immediately became "proximal."

\section{Lavukaleve}

Among Lavukaleve demonstratives there are paradigms of demonstrative pronouns and demonstrative modifiers, locative deictics, and a very rare set of demonstrative identifiers. The demonstrative pronouns consist of first and second person personal pronouns and two paradigms of third person demonstrative pronouns; there are no third person personal pronouns (Terrill 2003). The two paradigms of third person demonstrative pronouns differ in their anaphoric reference capabilities. One set is used for anaphoric reference to highly activated entities, while the other set is reserved for anaphoric reference to less activated entities (Terrill 2001).

The third person demonstrative pronouns and demonstrative modifiers both mark gender and distance inherently in their stems, and indeed differ formally only in their initial consonant (or lack thereof): for example, the third singular masculine, feminine, and neuter middle forms of the demonstrative pronoun from the activated paradigm are foina, foia, and foiga respectively; those forms from the semi-activated paradigm are 
oina, oia, and oiga respectively, and the demonstrative modifier forms are hoina, hoia, and hoiga respectively. As far as distance forms are concerned, the foiga-stems, that is the activated demonstrative pronouns, have the same distance specifications as the hoiga-stems, or demonstrative modifiers, formally at least, and apparently semantically and pragmatically too, although this remains to be tested. The oiga-stems, the semiactivated demonstrative pronouns, are typically only found in what corresponds formally to the middle distance form of the other demonstratives, although some forms corresponding to the proximate stems have rarely been noted to occur. As a very rough but convenient way of understanding these demonstrative types, foiga-stems can often be translated into English using pronouns, for example, 'he'; oiga-stems can be translated very roughly as something like 'he, who I was talking about before', and hoiga-stems roughly as something like 'that'. The relationship between these three demonstrative stem types is discussed in detail in Terrill (2003: ch. 8).

Also worth mentioning is a set of locational adverbs, which make the same formal distance distinctions as the demonstrative pronouns and demonstrative modifiers: hoka, hoika, heaka, and hoaka 'here, there, etc.'. The contrastive task elicited demonstrative modifiers; and it is to these that our discussion will be confined.

The demonstrative modifiers consist of four stems: hoga 'this-PX.sgn', hoiga 'that-NTRL.sgn', heaga 'that-DT.sgn', and hoaga 'that-UNSP.sgn' (cited in their neuter singular forms here). They mark gender and number, in agreement with their nominal head, and they also mark distance. The fourth term (hoaga, glossed unspecified) is used for nonspecific referents. That is, its most frequent use is for referring to entities which do not actually exist, or which are used as generic instances of a type. This fourth term hoaga is not compatible with a definite referent, so it is incompatible with all of the usages to be discussed below. See Terrill (forthcoming) for a description of the exophoric demonstrative system in Lavukaleve. The three remaining demonstrative modifiers hoga, hoiga, and heaga do, however, operate exophorically to express distance contrasts, as follows:

$\begin{array}{ll}\text { hoga } & \text { proximal (sg.n) } \\ \text { hoiga } & \text { distance-neutral (sg.n) } \\ \text { heaga } & \text { distal (sg.n) }\end{array}$

The demonstrative modifiers can appear with the presentative suffix $-r i$ (cf. [10] below) and the predicative suffix $-o / o m / v$. The presentative form of the demonstrative is typically used with an accompanying gesture.

To give an indication of the meaning and general function of these demonstrative modifiers, the following examples are illustrative. Note that 
these examples contain various person-number formatives of the three stems:

(6) Plantation-aul hoiva vo-na fo'foira

plantation-PL MOD.NTRL.PL 3PL.O-in work(F)

o-i-ham kini ma-fifi.

3SG.F.O-do-PURP ACT 3PL.S-Sit

'They came to work on those plantations.'

(7) Man hona?

what(M) MOD.NTRL.SG.M

'What's this?'

(8) Ami o-ki-v hova?

who(M) 3sG.S-shoot-PL MOD.PX.PL

'Who killed these [birds]?'

(9) rara hoga e-hamail mina matua

side(N) MOD.PX.SG.N 3sG.N.O-facing thing(F) old.coconut(F)

feo $k$.

3.SG.F.FOC EMPH

'... facing this side is a dry coconut.'

(10) Hoga-ri ke.

MOD.PX.SG.N-PSNV EMPH

'This one.' (pointing to thumb)

\subsection{Results of the contrastive demonstrative task}

The contrastive task was carried out with six speakers, in a total of four sessions (three sessions with one speaker each, and one session with three speakers together giving judgments). The sessions were recorded on minidisk and with pen and paper.

The results of the contrastive task are presented below. Whether or not speakers pointed did not affect the demonstrative choice, whereas whether or not they touched the referent did make a difference.

Table 6. Two referents displayed on the sagittal axis in front of the speaker, with speaker pointing and touching

\begin{tabular}{ll}
\hline Best & Bad \\
\hline$\square$ & $\begin{array}{l}\text { hogari (PX) } \\
\text { hogari (PX) }\end{array}$ \\
6 & 6 \\
\hline
\end{tabular}




\section{S. Meira and A. Terrill}

Table 7. Two referents displayed on the sagittal axis in front of the speaker, with speaker pointing but not touching

\begin{tabular}{llll}
\hline Best & Good & & Bad \\
\hline$\square$ & $\begin{array}{l}\text { heagari (DT) } \\
\text { hogari }(\mathrm{PX})\end{array}$ & heagari $(\mathrm{DT})$ & hogari $(\mathrm{PX})$ \\
hogari $(\mathrm{PX})$ & heagari $(\mathrm{DT})$ & hogari $(\mathrm{PX})$ & heagari $(\mathrm{DT})$ \\
3 & 3 & 1 & 2 \\
\hline
\end{tabular}

Table 8. Three objects displayed at equidistant intervals on the sagittal axis in front of the speaker, with the speaker pointing but not touching

\begin{tabular}{|c|c|c|}
\hline Best & Good & $\mathrm{Bad}$ \\
\hline hogari (PX) & heagari (DT) & heagari (DT) \\
\hline hogari (PX) & heagari (DT) & hoigari (NTRL) \\
\hline hogari (PX) & heagari (DT) & hogari (PX) \\
\hline 5 & 3 & 5 \\
\hline
\end{tabular}

Table 9. Three objects in two clusters, one close and two far away, on the sagittal axis in front of the speaker, with the speaker pointing but not touching

\begin{tabular}{|c|c|c|c|c|}
\hline Best & & Good & Dispreferred & $\mathrm{Bad}$ \\
\hline heagari (DT) & hogari $(\mathrm{Px})$ & heagari (DT) & hoigari (NTRL) & \\
\hline heagari (DT) & hogari $(\mathrm{PX})$ & heagari (DT) & hoigari (NTRL) & anything else \\
\hline hogari $(\mathrm{PX})$ & hogari $(\mathrm{PX})$ & heagari (DT) & hoigari (NTRL) & \\
\hline 2 & 3 & 3 & 3 & 3 \\
\hline
\end{tabular}

Table 10. Three objects in two clusters on the sagittal axis in front of the speaker, two close to the speaker and a single one further away, with the speaker pointing but not touching

\begin{tabular}{|c|c|c|c|c|}
\hline Best & Good & & Dispreferred & $\mathrm{Bad}$ \\
\hline heagari (DT) & hogari (PX) & heagari (DT) & hoigari (NTRL) & anything else \\
\hline hogari (PX) & hogari (PX) & heagari (DT) & hoigari (NTRL) & \\
\hline hogari (PX) & hogari (PX) & heagari (DT) & hoigari (NTRL) & \\
\hline 2 & 3 & 3 & 3 & 3 \\
\hline
\end{tabular}




\subsection{Discussion of results}

In all cases, the terms were used irrespective of the order in which they were mentioned. Speakers generally chose one order in which to mention each item, seemingly at random, and remained with this order through the whole session unless the researcher asked for a different order.

The results show that where objects were equidistant from each other, speakers used one term for all objects. When the objects were clustered into groups, speakers could still use one term for them, or they could use two terms. If speakers only used one term, they used either the proximal term or the distal term (the choice between proximal and distal depends on whether they touched the object; see below). Use of the neutral (middle) term was never volunteered, and only marginally accepted if the researcher suggested it.

If speakers used two terms, the proximal term was used for the object(s) closest to the speaker and the distal term was used for the other object(s). Even when there were three distinct clusters of objects, speakers did not use the three available terms; they used the proximal term for the cluster(s) closest to the speaker and the distal term for the other cluster(s).

It was mentioned above that there is a presentative form for demonstratives, consisting of the presentative suffix -ri added to a demonstrative stem. In the contrastive task, most demonstratives actually appeared in the presentative form, and speakers mostly pointed as they used it. In natural speech, too, there is a very high correlation between use of presentative demonstratives and pointing. However, it is not a $100 \%$ correlation, and it is possible for speakers to point and not use a presentative demonstrative, or use a presentative demonstrative and not point. In any case, pointing or not pointing does not appear to affect the distance term used. However, touching does. The proximal term must be used if a speaker touches the object. The neutral and distal terms cannot be used if a speaker touches the object.

The fact that with a pair or group of equidistant objects it was in all cases most appropriate to use the same distance form for referring to each object indicates that in such groupings, the contrastive context overrides distance considerations, and thus the distance-related meanings of the demonstratives are not generally used to make distinctions in contrastive function in table-top space. One interpretation of this is that, unless there is a good reason not to (as with clusters of differentially spaced objects) speakers tend to construe the table-top space as one frame, whereby all objects are seen as being in the same area. Under these circumstances 
distance contrasts are not relevant, and thus only one distance term is used.

However, when there are clear clusters of objects, speakers tend to construe more than one frame of space (i.e. the objects tend to be seen as being in different frames, or areas), and in these circumstances distance-differentiated demonstratives can be usefully used to distinguish them.

It has been argued elsewhere (Terrill forthcoming) that the neutral (middle) demonstrative term in Lavukaleve is a distance-neutral term. In that work it is shown that the proximal term is used for reference to objects close to the speaker, and the distal term is used for reference to other objects. If three objects are lined up in space, in whatever scale, the three available demonstrative terms are never used to refer noncontrastively to the three objects in such a line. Rather, either the proximal or the distal term is used to refer to all of them. Critically, while there is a prototypical space assigned by speakers to the proximal term, and there is a prototypical space associated with the distal term, there is no space prototypically associated with the neutral (middle) term. That is, with the proximal demonstrative, if one asks a Lavukaleve speaker, What does hoga (PX) mean? When can I use it?, an answer will typically be given in terms of examples of objects within arm's reach. Similarly, with the distal demonstrative, if one asks, What does heaga (DT) mean, and when can I use it?, an answer will typically be given in terms of an example indicating an object in large-scale geographical space, for instance, something at the other end of a football-field-sized area, or the next island. However, similar questions about the meaning of the neutral (middle) term hoiga cannot be answered by Lavukaleve speakers; it appears that there is no distance meaning associated with this term. The middle term is functionally unmarked in other ways as well; for instance, it is the form most frequently used in discourse anaphora, in both the demonstrative modifiers and demonstrative pronouns.

The analysis of the middle term in Lavukaleve as a distance-neutral term, which was based on an analysis of noncontrastive exophoric usages, is supported by the contrastive data. It seems that the middle term is not used to distinguish between contrasted objects in table-top space precisely because it does not have a distance value in its semantics, and thus it does not serve to make distance distinctions at all. Therefore, it is not useful for identifying contrasted objects based on their distance from the speaker. The contrastive task thus provides further support for the already existing analysis of this term as distance-neutral.

Once a speaker construes the table-top space as having objects in multiple areas to be distinguished by the demonstratives, the distance 
functions of the demonstratives are used. That is, in this case they are not used just for contrast like in English, in which under contrastive function, either the proximal or the distal term can felicitously be used; rather, in Lavukaleve the actual distance meanings of the demonstratives are invoked. Therefore, in these cases relative distance from speaker is always important; the proximal term must be used for the object(s) closer to the speaker, and the distal term for the object(s) further from the speaker, and not vice versa.

Touching is only compatible with the proximal demonstrative. This could be because for an object to be within touching range, it must be construed as being close to the speaker; in which case the proximal demonstrative is applicable. If a distal demonstrative is used, even in tabletop space, its relative distance meanings remain important, thus it is incompatible with touching.

Observations of contrastive demonstrative usage in natural contexts support the data obtained in this controlled task. Interestingly, the locational adverbs hoka 'here (proximal)', hoika 'there (neutral)', heaka 'there (distal)', hoaka 'there (unspecified)', which were mentioned briefly above, follow the same pattern of usage as the demonstrative modifiers in their contrastive function. In a story, a girl explains to her jealous husband how she and another man were sitting together innocently in the same room. She is concerned to show that they were sitting in separate areas albeit in the same room. She said:

$\begin{array}{llll}\text { Hoka-ri-v } & f i & \text { ngai a-me, } & \text { hoka-ri } \\ \text { here.PX-PSNV-PL } & \text { 3SG.N.FOC 1SG 1sG.S-continue here.PX-PSNV } \\ f i \quad n g a i & \text { a-fifi, hoka-ri } & f i \\ \text { 3SG.N.FOC 1SG } & \text { 1SG.S-Sit here.PX-PSNV } & \text { 3SG.N.FOC } \\ \text { oina } & \text { o-fifi. } & \\ \text { other.NTRL.SG.M } & \text { 3sG.S-sit } \\ \text { 'We were here, I was here, I sat here, the other one sat here.' }\end{array}$

The speaker uses the proximal form for both instances, referring to an area of space inside a room but out of arm's reach. Even though she is contrasting two different areas, she uses the proximal form to refer to both, rather than using two different distance forms. This data exactly parallels the contrastive use of the demonstrative modifiers in table-top space. It shows two interesting points: that the locational adverbs, which mark the same distance distinctions in their forms, operate in a similar fashion to the demonstrative modifiers. It also shows that contrastive usages beyond table-top space, and in a natural context, mirror the uses in table-top space which were elicited using the contrastive task. 


\section{Conclusions}

Wilkins (1999: 25) suggested that, “. . languages could look very similar in terms of 'simple referring', but very different in terms of 'contrastiveness'...." Lavukaleve and Tiriyó provide evidence in support of this suggestion. The noncontrastive exophoric use of demonstratives in these two languages is very similar (Meira forthcoming; Terrill forthcoming). However, the results of the contrastive task show that the two "middle" terms are actually quite distinct.

Lavukaleve hoiga is a true neutral, and, as such, does not show up in contrastive contexts. Its medial uses in noncontrastive contexts apparently arise from the pragmatic preemption of the semantic space of "distance" by the two other terms: since the proximal hoga is more felicitous for referents saliently close to the deictic center, and the distal heaga for those which are obviously distant, hoiga is left with the "no-man's land," the "medial" space. However, as has already been said, its semantics, its meaning seems not to include the notion of "medial," since such a feature would make hoiga obviously useful in distinguishing three objects located increasingly more distantly from the deictic center (speaker), and yet hoiga is not found in such contexts. In fact, no contrastive context, even with more than two referents, was capable of eliciting all three terms.

Tiriyó mërë, on the other hand, Is found in such contexts. Unlike in Lavukaleve, in Tiriyó it is perfectly possible, and even frequent in the contrastive task data, to employ the full three-term system (se(nï)/serë, mërë, ooni) when attempting to distinguish three referents. Even for two objects, all combinations of two terms compatible with the distance (i.e. such that the more distal term was used for the more distal referent, and the more proximal term for the more proximal referent) actually occurred: se(nï)/serë and mërë (proximal-middle), se(nï)/serë and ooni (proximal-distal), and mërë and ooni (middle-distal). The occurrence of every pair correlated with distance: when the two referents were placed relatively near the speaker, the proximal-middle option was favored; when the two referents were relatively far, the middle-distal choice was favored; if one was placed much farther away than the other, the proximaldistal response occurred. In other words, "distance" seems to be very much a part of the semantics of each of the three terms in the Tiriyó system. Although considerations based on noncontrastive use (Meira 2003b, forthcoming) suggest an analysis of mërë as an unmarked (i.e. neutral) distal, the contrastive task shows that it certainly is an unmarked (neutral) distal: "distance" is part of its semantics, not merely a pragmatic implicature given the presence of a proximal and a distal term. ${ }^{12}$ 
Thus, not only are not all three-term systems identical or isomorphic; even three-term systems that look similar in noncontrastive contexts can actually be different in contrastive contexts. This difference can be actually quite dramatic (since, for the systems described here, it actually implies that "distance" - an all-favorite candidate for an important feature in a demonstrative system - Is actually part of the semantics for the Tiriyó "middle" mërë, but NOT for the Lavukaleve "middle" hoiga.

The data presented here suggests that contrastive contexts are an important parameter of variation in the semantics of exophoric demonstrative systems. Moreover, the fact that contrastive contexts - in which the speaker attempts to distinguish one among several possible referents may actually cause interesting differences in demonstrative usage with respect to noncontrastive contexts - in which a speaker attempts to direct the addressee's attention to a single referent located somewhere in their vicinity - should also be taken into consideration in theoretical accounts of demonstratives (and perhaps even of deixis in general, in case similar effects can be registered for, e.g., temporal deixis). As Wilkins (1999) suggested, it is quite possible that contrastive contexts may represent independent dimensions along which demonstrative systems can vary.

Received 5 December 2001

Revised version received

KNAW/Leiden University

11 May 2004

Max Planck Institute for Psycholinguistics

\section{Appendix}

This is the transcript of a typical session of the Tiriyó elicitation. The speaker (SPK) is a young man (approximately 20 years old). He and the researcher (RES) sit on opposite sides of a small wooden table. The researcher places a large, hardcover notebook on the table, and then three pieces of paper with drawings representing a tree, the moon, and a house, on top of the notebook.

RES.: Ma, kure, serë nunnë ikuhtu, serë wewe ikuhtu, PTC well PX.INAN moon drawing PX.INAN tree drawing serë pakoro ikuhtu. PX.INAN house drawing 'So, well, this is a drawing of the moon, and this is a drawing of a tree, and this is a drawing of a house.'

SPK.: Aha. yes 'OK.' 

RES.: Ma, menjaarë sen-ton w-onan-jae, serë apo. Ene-h PTC now PX-INAN-COL 1-hide-PRES PX.INAN like look-IMPER pitë.
a.little
'Well, now I am hiding these (drawings), like this. Look (= pay attention).'

(Researcher turns the pieces of paper down, hiding the drawings. Then he scrambles them for half a minute. In the end, the three pieces of paper form a line on the sagittal axis in front of the speaker.)

RES.: Kure m-ene?

well 2-see:PST

'Did you look well? (= did you see what I did?)'

SPK.: Aha.

yes

'Yes.'

RES.: Ma, kure... [Pause]. Aano nai, wewe-pisi?

PTC well which 3.COP tree-DIM

'OK, well. . [Pause]. Which one is the little tree?'

SPK.: Sen. (He touches one of the pieces of paper.)

PX.INAN

'This one.'

RES.: Aano nai, pakoro-pisi?

which 3.COP house-DIM

'Which one is the little house?'

SPK.: Serë. (He touches another piece of paper.)

PX.INAN

'This one.'

RES.: Aano nai, nunnë-pisi?

which 3.COP moon-DIM

'Which one is the little moon?'

SPK.: Sen. (He touches the third piece of paper.)

PX.INAN

'This one.'

RES.: 'Serë' ka-to, ka-ewa manan? Kure=ta?

PX.INAN say-NZR say-NEG 2.COP good=NEG

Tïpato $=r o=t a$ ?

aligned. with.itself $=\mathrm{EMPH}=\mathrm{NEG}$

'You don't say "serë" (PX)? Is it bad? Is it wrong?'

SPK.: Aha... Owa... [Pause] Kure=nkërë nai, tïpato=ro.

yes no good $=$ still 3.COP aligned.with.itself $=\mathrm{EMPH}$

'Yes... No... [hesitation] It's good, too, it's correct.'

RES.: Atï?

wh.INAN

'What?' 
SPK.: 'Serë' ka-to, tïpato-no=ro.

PX.INAN say-NZR aligned.with.itself-NZR $=\mathrm{EMPH}$

'Saying "serë" (Px), it's perfectly all right.'

RES.: Aha, wi-puunë... [Pause]. Ma, in-ekantë-ewa ëmë ahtao, eeke yes 1-understand:PST PTC 3-point-NEG you if how mï-ka-n? Aano nai, pakoro-pisi?

2-say-PRES which 3.COP house-DIM

'OK, I see...' [Pause]. 'Well, and if you don't point, how do you say?

Which one is the little house?'

SPK.: Ooni. (He looks and lip-points at the farthest piece of paper.)

DT.INAN

'That one.' [distal]

RES.: Aano nai, nunnë-pisi?

which 3.COP moon-DIM

'Which one is the little moon?'

SPK.: Mërë. (He looks and lip-points at the piece of paper in the middle.) MD.INAN

'That one.' [medial]

RES.: Aano nai, wewe-pisi?

which 3.COP tree-DIM

'Which one is the little tree?'

SPK.: Serë. (He looks and lip-points at the nearest piece of paper.)

PX.INAN

'This one.' [proximal]

\section{Notes}

1. We would like to thank members of the Language and Cognition Group of the Max Planck Institute, Nijmegen, for discussion, advice, and ideas on many of the points raised in this article. In addition, we are grateful to Niclas Burenhult, Michael Dunn, and two anonymous reviewers for their very helpful comments on earlier drafts of this article. We are also grateful to members of the Tiriyó and Lavukaleve-speaking communities who contributed the data which made this work possible. Correspondence address: Leiden University, Faculteit der Letteren/TCLA, P.O. Box 9525, 2300 RA Leiden, The Netherlands. E-mail: s.meira@let.leidenuniv.nl.

2. Examples of grammars in which nothing other than such labels, or very brief descriptions such as "this (near speaker)," "that (distant from speaker)" are given to account for demonstrative usage are not difficult to find; even the classic descriptive grammars such as Derbyshire's (1985) grammar of Hixkaryana or Dixon's (1972) grammar of Dyirbal are examples of this phenomenon. Typologies are built on grammatical descriptions and must necessarily suffer from the limits imposed on them by the data available in grammatical descriptions.

3. Of the languages in their sample, Sre (Manley 1972) is perhaps the most interesting. One of Sre's six determiners is $d a$ ?, glossed 'that', which functions to identify "the second of two objects being compared or contrasted; in this sense it forms a pair with $d s$ ['this', i.e. proximal, or the first of two contrasted objects] in such constructions as sra? 
$d o / s r a$ ? da? 'this book'/ 'that book' where the focus is on discrimination rather than on relative distance" (Manley 1972: 151). An example of these demonstratives in contrast: "This $[d o]$ part is not level, that [da?] part is, so we must plant the rice that side" (Manley 1972: 153). It would be interesting to see how Sre demonstratives would be applied to a task like the one described in this article.

4. There may be indirect addressee effects in Tiriyó, though; cf. Meira (2003a).

5. We use the term "middle" as a cover term for the nonproximal, nondistal terms in both languages. However, in referring to each form individually, the term "medial" is used as the name of the Tiriyó nonproximal, nondistal demonstrative, and "neutral" as the name of the Lavukaleve nonproximal, nondistal demonstrative.

6. Tiriyó does not really have a class of "adjectives" (i.e. words specialized in modifying nouns); in fact, "modification" is not a grammatical phenomenon in the language, which tends to use independent nouns in apposition for situations in which European languages would employ modifying adjectives ('two tall women' = 'women, the tall ones, the two/couple'; cf. Meira [1999a: 525-532] for further details). The same is true for demonstratives: 'that book' = 'that one, book'.

7. The transcription system used here is taken from Meira (1999a). Possibly ambiguous symbols: $\ddot{i}=[\mathrm{i}] \sim[\mathrm{u}] ; \ddot{e}=[\mathrm{\jmath}] \sim[\Lambda] ; o=[\mathrm{\jmath}] \sim[\mathrm{o}] ; \quad e=[\mathrm{\varepsilon}] \sim[\mathrm{e}] ; j=\mathrm{IPA}[\mathrm{j}]$, $s=[\mathrm{c}] \sim\left[\int\right] \sim[\mathrm{s}] ; r=[\mathrm{r}] \sim[\mathrm{r}] \sim[1] ; n=[\mathrm{n}]$, but [n] if word-final or followed by $k$, $[\mathrm{m}]$ if followed by [p], and $[\mathrm{n}]$ if followed by $\mathrm{j}$. Syllables in parentheses change form depending on the following material. For instance, ( $m o$ ) is $m o[\mathrm{mo}]$ if, in the same phonological word (including affixes and clitics), it is followed by a non-CV syllable, but $n$ [y] otherwise. Thus, irëto(mo) occurs by itself as irëton [irə:ton], but, with the clitic nkërë 'still', it becomes irëtomo=nkërë [irə:tomınkərə]. Cf. Meira (1999a: 77-94, 1999b).

8. Abbreviations: ACT action particle; ANAPH anaphoric; COL collective; COP copula; DEM demonstrative; DIM diminutive; DS distal; EMPH emphatic; F feminine; FOC focus; IMPER imperative; INACC inaccessible; INAN inanimate; LOC locative; MD middle; MOD demonstrative modifier; N neuter; NEG negative; NTRL neutral; NZR nominalizer; o object; PL plural; PSNV presentative; PST past; PRES present; PTC particle; PURP purposive; PX proximal; s subject; M masculine; SG singular.

9. Stars are the only known exception: they are treated as animate. Note that other celestial bodies (sun, moon, clouds) are treated as inanimate. Among younger speakers, even stars are often treated as inanimate; older speakers, however, quite consistently prefer animate forms.

10. Given the nature of the task, only inanimate demonstratives occurred in the answers. The animate pronouns are expected to parallel their inanimate counterparts in actual contrastive usage. A quick check was done by using drawings of animate referents and asking one speaker if he could refer to them with animate demonstratives. He did, and their use was not different from that of the equivalent inanimate demonstratives, as one would expect. Of course, more research remains necessary.

11. Preliminary results (Meira 2003b) suggest that the difference between the two proximal pronouns is "newness": serë tends to refer to "new," "surprising" entities while se (nï) is preferred for "old," "already known" entities. This suggests that attention direction may be playing an important role: the choice of serë or se(nï) might depend on whether the addressee already has his attention on the referent that the speaker wishes to mention or not. More research is necessary to determine this point. If this is true, then one should expect se(ni) and serë to be distinguishable in certain contrastive contexts ('not this one that you're looking at; this other one here!'). However, no such distinctions were observed in the contrastive task data. A possible explanation 
is given by the nature of the task. The researcher (addressee) and the speaker were both watching the same square pieces of paper, so that both the addressee's-attention-is-onit and the addressee's-attention-is-not-yet-on-it construals were always available to the speaker (i.e. these variables were not controlled).

12. There is some evidence that the "distal" ooni may be a recent newcomer in the demonstrative field. According to the judgments of two older speakers, ooni is much better as an adverb ('over there, yonder') than as a pronoun (one of the two speakers did not accept sentences in which it was used as a pronoun). Younger speakers, however, have absolutely no problems in using ooni as a pronoun, with all syntactic and morphological properties that this status allows. One might suggest that mërë used to be the distal form, contrasting with se(nï)/serë, and that ooni and mërë are now in competition in the distal area of the demonstrative semantic field. This suggestion, however, must be regarded as speculative.

\section{References}

Anderson, Stephen R.; and Keenan, Edward L. (1985). Deixis. In Language Typology and Syntactic Description, Timothy Shopen (ed.), 259-308. Cambridge: Cambridge University Press.

Derbyshire, Desmond C. (1985). Hixkaryana and Linguistic Typology. Dallas, TX: Summer Institute of Linguistics and the University of Texas at Arlington.

Diessel, Holger (1999). Demonstratives: Form and Function. Amsterdam and Philadelphia: John Benjamins.

Dixon, R. M. W. (1972). The Dyirbal Language of North Queensland. Cambridge: Cambridge University Press.

- (2003). Demonstratives: a cross-linguistic typology. Studies in Language 27, 61-112.

Dunn, Michael; and Meira, Sérgio (eds.). (in prep.). Demonstratives in Use.

Fillmore, Charles J. (1982). Towards a descriptive framework for spatial deixis. In Studies in Deixis and Related Topics, R. J. Jarvella and W. Klein (eds.), 31-59. Chichester and New York: John Wiley and Sons.

Himmelmann, Nikolaus P. (1996). Demonstratives in narrative discourse: a taxonomy of universal uses. In Studies in Anaphora, Barbara Fox (ed.), 205-254. Amsterdam and Philadelphia: John Benjamins.

Levinson, Stephen C. (1983). Pragmatics. Cambridge and New York: Cambridge University Press.

Lyons, John (1977). Semantics. Cambridge and New York: Cambridge University Press.

Manley, Timothy M. (1972). Outline of Sre Structure. Oceanic Linguistics Special Publications no. 12. Honolulu: University of Hawaii Press.

Marmaridou, Sophia S. A. (2000). Pragmatic Meaning and Cognition. Pragmatics and Beyond New Series 72. Amsterdam and Philadelphia: John Benjamins.

Meira, Sérgio (1999a). A grammar of Tiriyó. Unpublished doctoral dissertation, Rice University, Houston, Texas. (To appear in the Mouton Grammar Series, Mouton de Gruyter.)

- (1999b). Syllable reduction and ghost syllables in Tiriyó. In XXV LACUS Forum, Shin Ja J. Hwang and Arle R. Lommel (eds.), 125-131. Fullerton, CA: Linguistic Association of Canada and the United States (LACUS).

- (2003a). "Addressee effects" in demonstrative systems: the cases of Tiriyó and Brazilian Portuguese. In Deictic Conceptualization of Space, Time and Person, Friedrich Lenz 


\section{S. Meira and A. Terrill}

(ed.), 3-12. Pragmatics and Beyond New Series 112. Amsterdam and Philadelphia: John Benjamins.

- (2003b). Les démonstratifs proximaux non-animés de la langue tiriyo (caribe): une étude de corpus. Amérindia 28, 183-200.

- (forthcoming). Non-contrastive exophoric uses of Tiriyó demonstratives. In Demonstratives in Use, Michael Dunn and Sérgio Meira (eds.).

Terrill, Angela (2001). Activation in Lavukaleve pronouns: oia versus foia. Linguistic Typology $5,67-90$.

- (2003). A Grammar of Lavukaleve. Mouton Grammar Library No. 30. Berlin and New York: Mouton de Gruyter.

- (forthcoming). Exophoric demonstratives in Lavukaleve. In Demonstratives in Use, Michael Dunn and Sérgio Meira (eds.).

Wilkins, David (1999). Eliciting contrastive use of demonstratives for objects within close personal space (all objects well within arm's reach). In Manual for the 1999 Field Season, David Wilkins (ed.), 25-28. Nijmegen: Language and Cognition Group, Max Planck Institute. 